\title{
Uji Kelayakan Panduan Praktikum Perkembangan Hewan Berbasis Inkuiri pada Materi Metamorfosis
}

\author{
Ayu Mutoharoh ${ }^{1)}$, Jodion Siburian ${ }^{1,{ }^{*}}$, Winda Dwi Kartika ${ }^{1)}$ \\ ${ }^{1)}$ Program Studi Pendidikan Biologi, Fakultas Keguruan dan Ilmu Pendidikan, Universitas Jambi \\ *jdsiburian@gmail.com
}

Abstrak: Penelitian bertujuan untuk menghasilkan panduan praktikum berbasis inkuiri yang layak dari segi materi dan media. Berdasarkan angket studi pendahuluan yang diisi oleh mahasiswa yang telah mengontrak mata kuliah perkembangan hewan, ditemukan berbagai permasalahan pada praktikum metamorfosis. Permasalahan tersebut diantaranya mahasiswa masih mengalami kesulitan mendapatkan hasil yang sesuai dengan teori, masih membutuhkan panduan praktikum yang lebih detail, penggunaan alat dan bahan yang lebih spesifik, dan penambahan prosedur kerja panduan praktikum yang lebih rinci. Oleh karena itu, perlu dikembangkanlah panduan praktikum perkembangan hewan pada materi metamorfosis. Penelitian pengembangan menggunakan model 4D (Four D). Penelitian juga mengulas tahap pengembangan pada tahap 4D (Four D). Analisis data yang dilakukan adalah deskriptif kualitatif dan kuantitatif. Hasil penelitian diperoleh rata-rata validasi materi tahap 1 sebesar 51,18\% (kategori cukup baik), validasi tahap 2 sebesar 73,38\%, dan validasi tahap 3 sebesar 91,06\%. Sedangkan validasi media tahap 1 diperoleh sebesar 37,68\% (kategori cukup baik), validasi tahap 2 sebesar 61,44\% (kategori baik), dan validasi tahap 3 sebesar 90,17\% (kategori sangat baik). Proses validasi materi dan media dilakukan bertahap dan mengalami perbaikan panduan praktikum metamorfosis dan disimpulkan layak untuk digunakan.

Kata Kunci: Panduan Praktikum, Inkuiri, Metamorfosis

\section{PENDAHULUAN}

Praktikum adalah suatu strategi pembelajaran yang dapat memungkinkan mahasiswa untuk bisa mempraktikkan atau menstimulasi teori yang ada melalui metode empiris melibatkan kemampuan afektif, psikomotorik, maupun kognitif mahasiswa (LKPP-Unhas, 2015, p. 11). Menurut Widyaningrum \& Wijayanti (2019, p. 437) panduan praktikum merupakan salah satu media pembelajaran yang memuat isi mengenai prosedur pelaksanaan kegiatan praktikum sehingga dalam implementasinya dapat membantu kelancaran prosesnya bagi pendidik dan siswa. Panduan praktikum bermanfaat agar mahasiswa dapat melaksanakan kegiatan praktikum dengan sistematis dan terarah (Purnamasari \& Setiyadi, 2019, p. 123) sehingga ditemukan penyelesaian masalah yang relevan (Festiana, et al., 2014, p. 53). Selain itu, apabila praktikum dilaksanakan dengan standar yang ada di dalam panduan praktikum juga akan berdampak pada meningkatnya kualitas pembelajaran mahasiswa (Agustina \& Ningsih, 2017, p. 34).

Kegiatan praktikum memberikan pengalaman belajar bagi mahasiswa. Salah satu pembelajaran yang memerlukan kegiatan praktikum adalah perkembangan hewan pada materi metamorfosis. Metamorfosis merupakan proses perkembangan fase hidup hewan yang dimulai dari tahap embriologi hingga menjadi dewasa yang memiliki perbedaan bentuk pada setiap fasenya. Metamorfosis dapat juga diartikan sebagai proses perkembangan yang didahului oleh tahap larva yang fungsional dan hidup bebas dan menghasilkan tahap juvenil yang fungsional (Calado and Leal, 2015, p. 6). Metamorfosis umumnya terjadi pada serangga dan amfibi (Truman, 2019). Metamorfosis amfibi (katak) adalah proses rumit yang melibatkan perubahan histologis dan fisiologis yang substansial: penyerapan ekor berudu yang ekstensif, perkembangan kelenjar kulit multiseluler yang kompleks, dan penyerapan insang sebagai gas menjadi paru-paru sehingga amfibi dapat beradaptasi dari lingkungan akuatik ke lingkungan terestrial (McGarry, 2013). Fase metamorfosis pada katak terdiri dari tahap telur, berudu, katak muda, dan katak dewasa. Berudu berkembang dalam dua tahap, yaitu tahap embrio dan tahap larva (Suryanti, et al., 2020, p. 52). 
Pelaksanaan praktikum metamorfosis berkaitan erat dengan adanya panduan praktikum. Akan tetapi, kenyataan di lapangan menunjukkan bahwa panduan praktikum khususnya metamorfosis belum disesuaikan dengan perkembangan pengetahuan saat ini. Berdasarkan angket studi pendahuluan yang diisi oleh 15 orang yang telah mengontrak mata kuliah perkembangan hewan, $60 \%$ mahasiswa sulit mendapatkan hasil yang sesuai dengan teori khususnya pada materi metamorfosis, $60 \%$ mahasiswa menganggap panduan praktikum yang sudah ada belum menjelaskan secara detail materi metamorfosis, 33,3\% mahasiswa menggunakan alat dan bahan yang kurang tepat, dan 26,7\% mahasiswa kurang memahami prosedur kerja pada panduan praktikum. Oleh karena itu, perlu dikembangkan panduan praktikum yang dapat meningkatkan pengetahuan mahasiswa, membuat mahasiswa mampu melaksanakan praktikum secara mandiri dan mengatasi beberapa kendala lainnya.

Praktikum perkembangan hewan materi metamorfosis akan lebih menarik dan bermakna apabila kegiatan tersebut dilaksanakan menggunakan panduan praktikum berbasis inkuiri. Pembelajaran inkuiri dapat membuat mahasiswa terlibat secara kognitif baik dalam berpikir, membuat keputusan, dan membuat persoalan yang terkait dengan materi. Selain dapat membuat mahasiswa menguasai materi pelajaran, pembelajaran inkuiri juga dapat meningkatkan keterampilan metakognitif, hasil belajar, dan aktivitas serta kinerja mahasiswa saat proses pembelajaran (Toyep, 2012, p. 122). Menurut Rodiyana (2015, p. 34) pembelajaran inkuiri dapat mengembangkan kemampuan berpikir kreatif mahasiswa dengan efisien. Pengembangan panduan praktikum perkembangan hewan berbasis inkuiri pada materi metamorfosis menjadi solusi untuk mengatasi beberapa kendala yang dihadapi mahasiswa dalam praktikum.

Penelitian ini merupakan kegiatan uji coba kelayakan panduan praktikum yang dilakukan oleh validator ahli. Hierarki pengembangan panduan praktikum pada tahap validasi oleh ahli adalah salah satu tahap yang penting. Pada tahapan development dalam model 4D (Four D), panduan praktikum yang telah dikembangkan harus melalui tahap validasi oleh para ahli dibidang bahan ajar yang dikembangkan tersebut. Beberapa aspek yang harus divalidasi atau diuji kelayakannya yaitu validasi materi dan validasi media Sugiyono (2018). Jadi, penelitian ini bertujuan untuk menghasilkan panduan praktikum perkembangan hewan berbasis inkuiri pada materi metamorfosis yang layak diujicobakan ditinjau dari aspek kelayakan materi dan media.

\section{METODE}

Metode penelitian yang dilakukan adalah penelitian pengembangan atau $\mathrm{RnD}$ (Research and Development). Penelitian dilakukan untuk mengembangkan panduan praktikum materi metamorfosis berbasis inkuiri. Model pengembangan yang digunakan dalam penelitian ini adalah model pengembangan 4D (Four D). Model pengembangan 4D terdiri atas 4 tahap utama yaitu: Define (Pendefinisian), Design (Perancangan), Develop (Pengembangan) dan Disseminate (Penyebaran).

Penelitian ini mengulas tahap Development (Pengembangan). Tahap Development merupakan proses merevisi panduan praktikum yang telah disusun pada tahap desain. Adapun revisi yang dilakukan berdasarkan saran ahli materi dan media selama proses validasi. Instrumen penelitian yang digunakan pada tahap Development adalah lembar validasi ahli materi dan ahli media.

Analisis data yang dilakukan terdiri dari deskriptif kualitatif dan deskriptif kuantitatif. Pada analisis kualitatif dilakukan olah data yang berupa saran, kritik, dan komentar yang berasal dari validator ahli materi dan ahli media. Sedangkan analisis statistik deskriptif dilakukan olah data yang diperoleh dari instrumen lembar validasi. Adapun analisis data kuantitatif akan menghasilkan penilaian terhadap seluruh aspek yang diukur dengan skala likert. Setiap indikator yang diukur diberikan skor skala 1-5, yaitu 5 (sangat baik/sangat layak), 4 (baik/layak), 3 (cukup baik/cukup layak), 2 (tidak baik/tidak layak), dan 1 (sangat tidak baik/sangat tidak layak) (Sugiyono, 2018). Data akan dikonversi dalam bentuk persentase dengan rumus sebagai berikut:

$$
\text { Kevalidan }=\frac{\text { Jumlah skor yang diperoleh }}{\text { Jumlah skor maksimum }} \times 100 \%
$$

Tabel 1. Kriteria Kelayakan Media

\begin{tabular}{ccc}
\hline No & Skor Persentase $(\%)$ & Klasifikasi Validasi \\
\hline I & $80-100$ & Sangat Baik (SB)/Sangat Layak (SL) \\
2 & $60-80$ & Baik (B)/Layak (L)
\end{tabular}




\begin{tabular}{ccc}
3 & $40-60$ & Cukup Baik (CB)/Cukup Layak (CL) \\
4 & $20-40$ & Kurang Baik (KB)/Kurang Layak( KL) \\
5 & $0-20$ & Sangat Tidak Baik (STB)/Sangat Tidak Layak(STL) \\
\hline
\end{tabular}

\section{HASIL DAN PEMBAHASAN}

\section{Panduan Praktikum Materi Metamorfosis Berbasis Inkuiri}

Panduan praktikum metamorfosis yang telah didesain memiliki komponen yang terdiri dari pendahuluan, isi, dan penutup. Pendahuluan terdiri dari cover depan, identitas pemilik buku, kata pengantar, daftar isi, daftar gambar dan tata tertib praktikum. Pada bagian isi terdiri dari komponen judul praktikum, tujuan praktikum, kolom “Cari Tahu!”, kolom “Tahukah Kamu?”, Dasar Teori, Catatan Kaki, kolom “Ayo Berpikir!”, kolom “Info Penting”, kolom "Sekilas Info", Studi Kasus, Rumusan Masalah, Hipotesis Sementara, Alat dan Bahan, Prosedur Kerja, Tabel Hasil, Kesimpulan, Pertanyaan Pasca Praktikum, dan Kolom "Pojok Informasi”. Penutup terdiri dari format laporan, daftar rujukan, daftar tautan eksternal, profil penyusun dan cover penutup.

Panduan praktikum sesuai dengan pembelajaran inkuiri yang kegiatannya memiliki enam sintaks, yaitu orientasi/persiapan, merumuskan masalah, merumuskan hipotesis, mengumpulkan data, menguji hipotesis dan merumuskan kesimpulan. Menurut Rodiyana (2015, p. 35) pembelajaran inkuiri memiliki pengaruh positif dan signifikan terhadap kemampuan berpikir kreatif karena di dalamnya mahasiswa dituntut untuk mampu membuat ide dan hal baru, berlatih mengatur rincian ide kemudian mengungkapkannya, dan secara berkelompok dapat mengutarakan solusi dari permasalahan tertentu dalam waktu yang singkat.

Panduan praktikum materi metamorfosis berbasis inkuiri disusun berdasarkan komponen panduan praktikum yang baik. Panduan praktikum yang digunakan sebaiknya memiliki beberapa kriteria, diantaranya adalah mampu mendorong mahasiswa untuk berpikir kritis, mengembangkan kemampuan inkuiri (mencari tahu) mahasiswa dan mengajak mahasiswa menjadi lebih aktif dalam kegiatan praktikum. Kaidah penulisan yang standar harus dipenuhi dalam penulisan panduan praktikum agar dapat mencapai tujuan praktikum, kompetensi dasar, dan indikator capaian yang telah disusun dalam Rencana Program Semester (RPS) praktikum. Panduan praktikum dengan penulisan standar minimal juga dapat berpengaruh terhadap jalannya praktikum apakah akan berjalan dengan baik atau tidak (Agustina dan Ningsih, 2017, p. 35).

Setelah panduan praktikum didesain maka selanjutnya dilakukan proses validasi oleh ahli materi dan media. Adapun tujuan validasi produk adalah agar produk yang telah dikembangkan layak diujicobakan ke mahasiswa. Idealnya media pembelajaran yang dikembangkan perlu diperiksa oleh para ahli, khususnya mengenai ketepatan isi, materi pelajaran, kesesuaian dengan tujuan pembelajaran, desain fisik dan lain-lain (Aminah, 2015). Hal tersebut juga didukung oleh Suparman, Badjuri, \& Anwar (2018) yang menyatakan bahwa sebelum digunakan dalam kegiatan pembelajaran hendaknya media pembelajaran telah mempunyai status "valid/layak".

Panduan praktikum metamorfosis sebagai media pembelajaran yang dikembangkan dapat dikatakan berkualitas jika memenuhi beberapa kriteria, yaitu: validitas dilakukan dengan validasi dengan memberikan draf panduan praktikum dan angket kepada dosen ahli materi dan media (Samsu et al., 2020). Pada penelitian ini validasi materi panduan praktikum dilakukan dua kali sedangkan validasi media dilakukan sebanyak tiga kali. Hasil penilaian masing-masing validator ahli materi dan media dihitung persentase keseluruhan guna mengetahui kelayakan dari produk yang dikembangkan.

\section{Penilaian Kelayakan Panduan Praktikum Oleh Validator Ahli Materi}

Pada penelitian 4D (Four D) tahap pengembangan dilakukan validasi oleh validator ahli materi dan media. Validasi yang pertama dilakukan yaitu validasi materi. Aspek yang dinilai dari validasi materi yaitu aspek kelayakan isi, penyajian dan kelayakan bahasa. Validasi materi dilakukan sebanyak tiga kali. Hasil validasi tahap 1 memiliki rata-rata secara keseluruhan sebesar 51,18\% kategori cukup baik sehingga belum layak diujicobakan dan dilakukan validasi tahap 2. Hasil validasi tahap 2 terjadi peningkatan rata-rata yaitu sebesar $73,38 \%$ dengan kategori baik. Selanjutnya, dilakukan validasi tahap 3 dengan rata-rata 91,06\% dengan kategori sangat baik dan sudah layak diujicobakan. Hal tersebut dapat diamati pada Tabel 2 sebagai berikut. 
Tabel 2. Penilaian Kelayakan Materi Panduan Praktikum

\begin{tabular}{|c|c|c|c|c|c|c|}
\hline \multirow[b]{2}{*}{ No } & \multirow[b]{2}{*}{ Validasi Ke- } & \multicolumn{3}{|c|}{ Aspek Penilaian } & \multirow[b]{2}{*}{$\begin{array}{c}\text { Rata-Rata } \\
\text { Keseluruhan (\%) }\end{array}$} & \multirow[b]{2}{*}{ Kriteria } \\
\hline & & $\begin{array}{l}\text { Kelayakan } \\
\text { Isi (\%) }\end{array}$ & $\begin{array}{c}\text { Kelayakan } \\
\text { Penyajian (\%) }\end{array}$ & $\begin{array}{c}\text { Kelayakan } \\
\text { Bahasa (\%) }\end{array}$ & & \\
\hline 1 & Validasi Tahap 1 & 54,28 & 47,27 & 52 & 51,18 & Cukup Baik (CB) \\
\hline 2 & Validasi Tahap 2 & 71,42 & 72,72 & 76 & 73,38 & Baik (B) \\
\hline 3 & Validasi Tahap 3 & 94,28 & 90,9 & 88 & 91,06 & Sangat Baik (SB) \\
\hline
\end{tabular}

Penilaian validasi materi terbagi menjadi tiga aspek, yaitu aspek kelayakan isi, kelayakan penyajian dan kelayakan bahasa. Pada aspek kelayakan isi rata-rata hasil validasi materi tahap 1 yaitu 54,28\%, hasil validasi tahap 2 sebesar 71,42\%, dan hasil validasi tahap 3 yaitu sebesar 94,28\%. Menurut Kartikasari \& Widodo (2015) aspek kelayakan isi terdiri dari cakupan materi, keakuratan materi, dan kesesuaiannya dengan perkembangan ilmu dan teknologi saat ini. Beberapa indikator tersebut dapat menilai sejauh mana tingkat kelayakan isi materi. Saran yang diberikan oleh validator ahli materi adalah untuk menambah cakupan materi jenis-jenis metamorfosis yang terjadi pada hewan.

Aspek penilaian materi selanjutnya adalah kelayakan penyajian. Rata-rata hasil validasi aspek kelayakan penyajian pada tahap 1 yaitu 47,27\%, validasi tahap 2 sebesar $72,72 \%$, dan terus meningkat di validasi tahap 3 sebesar 90,9\%. Adapun aspek kelayakan penyajian terdiri dari teknik penyajian, pendukung penyajian dan kelengkapan penyajian. Isi dari teknik penyajian materi adalah mengenai konsistensi sistematika penyajian dan adanya variasi dari penyajian materi. Bagian pendukung penyajian memuat pembangkit motivasi tentang cara membuat peserta didik berpartisipasi dalam kegiatan pembelajaran melalui kegiatan penyediaan pertanyaan. Sedangkan kelengkapan penyajian menunjukkan adanya bagian isi, pendahuluan, dan penutup pada media yang dikembangkan (Rismawati, Widodo \& Agustina, 2015).

Pada aspek kelayakan bahasa didapatkan bahwa penilaian validasi tahap 1 sebesar 52\%, validasi tahap 2 mengalami peningkatan dengan nilai $76 \%$, dan terus meningkat di validasi tahap 3 sebesar $88 \%$. Aspek kelayakan bahasa dilihat dari beberapa aspek yaitu komunikatif dan kesesuaian dengan kaidah bahasa Indonesia. Komunikatif dapat dinilai berdasarkan bahasa yang digunakan dalam menyampaikan pesan atau informasi yang mudah dimengerti oleh mahasiswa. Sedangkan aspek kesesuaian dengan kaidah bahasa dinilai dari ketepatan dalam memilih tata bahasa dan ejaan menjadi kalimat yang efektif yang mengacu pada kaidah bahasa Indonesia yang baik dan benar (Purnanto \& Mustadi, 2018; Sari, Hasnunidah \& Marpuang, 2018). Validator materi memberikan saran terhadap aspek kelayakan bahasa berupa memperbaiki struktur kalimat yang kurang tepat dan penggunaan kata yang efektif.

\section{Penilaian Kelayakan Panduan Praktikum Oleh Validator Ahli Media}

Pada penelitian ini dilakukan validasi oleh validator ahli media sebanyak tiga kali. Hasil validasi media diperoleh validasi tahap 1 dengan persentase 37,68\% termasuk kategori cukup baik, lalu pada validasi tahap 2 meningkat menjadi 61,44\% dengan kategori baik, dan selanjutnya pada validasi tahap 3 memiliki peningkatan dengan kategori sangat baik yaitu persentase sebesar 90,17\%. Hasil persentase tersebut dapat diamati pada Tabel 3 berikut ini.

Tabel 3. Penilaian Kelayakan Media Panduan Praktikum

\begin{tabular}{|c|c|c|c|c|c|}
\hline \multirow[b]{2}{*}{ No } & \multirow[b]{2}{*}{ Validasi Ke- } & \multicolumn{2}{|c|}{ Aspek Penilaian Kegrafikan } & \multirow[b]{2}{*}{$\begin{array}{c}\text { Rata-Rata } \\
\text { Keseluruhan (\%) }\end{array}$} & \multirow[b]{2}{*}{ Kriteria } \\
\hline & & $\begin{array}{l}\text { Desain cover } \\
\text { Panduan (\%) }\end{array}$ & $\begin{array}{c}\text { Desain Isi } \\
\text { Panduan (\%) }\end{array}$ & & \\
\hline 1 & Validasi Tahap 1 & 37,16 & 38,2 & 37,68 & Cukup Baik (CB) \\
\hline 2 & Validasi Tahap 2 & 60,07 & 62,81 & 61,44 & Baik (B) \\
\hline 3 & Validasi Tahap 3 & 89,91 & 90,43 & 90,17 & Sangat Baik (SB) \\
\hline
\end{tabular}

Berdasarkan Tabel 3 dapat diketahui bahwa terjadi peningkatan dari tahap validasi 1 sampai validasi ke 3. Pada penilaian kegrafikan dari desain cover tahap 1 sampai tahap 3 terjadi peningkatan yakni mulai dari 37,16\%, 60,07\%, dan 89,91\%. Penilaian desain cover dilakukan berdasarkan aspek kesesuaian warna background dengan warna teks, ukuran huruf, dan ilustrasi cover. Pada desain isi panduan praktikum metamorfosis 
didapatkan penilaian dari tahap 1 sampai tahap 3 yaitu 38,2\%,62,81\%, dan 90,43\%. Penilaian tersebut dilakukan berdasarkan konsistensi tata letak susunan judul dan sub judul panduan praktikum, ilustrasi, serta tipografi huruf panduan praktikum.

Aspek kegrafikan yang dinilai dari panduan praktikum terdiri dari desain cover dan desain isi panduan praktikum. Adapun saran perbaikan yang diberikan oleh validator ahli media terhadap panduan praktikum metamorfosis adalah memperbaiki gambar dan warna cover agar perpaduan warna lebih baik, menambahkan ilustrasi gambar serta memperjelas gambar isi panduan. Menurut Safitri \& Hartati (2016) menyatakan bahwa adanya unsur kegrafikan yang baik dan memadai pada panduan praktikum diharapkan mampu memotivasi mahasiswa dalam memahami materi yang diberikan.

\section{SIMPULAN}

Berdasarkan hasil penelitian yang dilakukan dapat disimpulkan bahwa uji kelayakan materi dan media panduan praktikum metamorfosis berbasis inkuiri dapat dikategorikan layak untuk diujicobakan. Validasi media dan materi dilakukan masing-masing sebanyak tiga kali dengan setiap tahap terus mengalami peningkatan karena adanya perbaikan terhadap panduan praktikum yang dikembangkan. Hasil validasi materi diperoleh validasi tahap 1 51,18\% kategori cukup baik menjadi 73,38\% kategori baik dan selanjutnya pada validasi tahap 3 sebesar 91,06\% kategori sangat baik. Hasil validasi media diperoleh validasi tahap 1 sebesar 34,68\% kategori cukup baik, validasi tahap 2 sebanyak 61,44\% kategori baik, dan validasi tahap 3 dengan persentase 90,17\% memiliki kategori sangat baik. Validasi materi dan media yang telah dilakukan menunjukkan bahwa panduan praktikum perkembangan hewan berbasis inkuiri materi metamorfosis layak diujicobakan.

\section{Ucapan Terima Kasih}

Ucapan terima kasih disampaikan kepada pihak-pihak yang telah membantu hingga selesainya uji kelayakan panduan praktikum metamorfosis ini. Kepada mahasiswa Program Studi Pendidikan Biologi yang terlibat dalam penelitian, tim pengampu mata kuliah Perkembangan Hewan dan Fakultas Keguruan dan Ilmu Pendidikan Universitas Jambi atas hibah dana PNBP yang diberikan sehingga pengembangan panduan ini dapat diselesaikan dengan baik.

\section{Daftar Pustaka}

Agustina, P. and Ningsih, I. W. (2017) 'Observasi Pelaksanaan Praktikum Biologi di Kelas XI SMA Muhammadiyah 1 Surakarta T . A . 2015 / 2016 Ditinjau dari Standar Pelaksanaan Praktikum Biologi The Observation of Biology Practical in Grade XI SMA Muhammadiyah 1 Surakarta 2015 / 2016 Based on Bio', Bioeducation Journal, 1(1), pp. 34-43.

Aminah, N. (2015) 'Analisis Validasi Pengembangan Perangkat embelajaran Matematika dengan Model Plomp Pada Materi Geometri', Aksioma: Jurnal Matematika dan Pendidikan Matematika, 6(1), pp. 1-9. doi: https://doi.org/10.26877/aks.v6i1/Maret.857.

Calado, R. and Leal, M. C. (2015) Trophic Ecology of Benthic Marine Invertebrates with Bi-Phasic Life Cycles: What Are We Still Missing? 1st edn, Advances in Marine Biology. 1st edn. Elsevier Ltd. doi: 10.1016/bs.amb.2015.07.001.

Festiana, I., -, Sarwanto and -, Sukarmin (2014) 'Pengembangan Modul Fisika Berbasis Masalah Pada Materi Listrik Dinamis Untuk Meningkatkan Kemampuan Berpikir Kreatif Siswa Sma', Inkuiri, 3(3), pp. 53-64. doi: 10.20961/inkuiri.v3i2.9682.

Kartikasari, Y. and Widodo, M. (2015) 'Kelayakan Isi dan Bahasa Pada Buku Teks Bupena Bahasa Indonesia Kelas VII', Jurnal Kata (Bahasa, Sastra, dan Pembelajarannya), 3(3), pp. 1-6.

LKPP-Unhas (2015) 'Bahan Ajar, Buku Ajar, Modul, dan Panduan Praktik', Pendidikan, p. 12.

McGarry, M. P. (2013) The Evolutionary Origins and Presence of Eosinophils in Extant Species, Eosinophils in Health and Disease. Amsterdam: Elsevier Inc. doi: 10.1016/B978-0-12-394385-9.00002-X.

Purnamasari, S. and Setiyadi, M. W. (2019) 'Pengaruh Zat Kimia Pada Berbagai Suhu Terhadap Denyut Jantung Katak (Rana Sp.) Dalam Upaya Pengembangan Buku Petunjuk Praktikum Fisiologi Hewan Sry', 7(2), pp. 123-131.

Purnanto, A. W. and Mustadi, A. (2018) 'Analisis Kelayakan Bahasa Dalam Buku Teks Tema 1 Kelas I Sekolah 
Dasar Kurikulum 2013', Profesi Pendidikan Dasar, 3(2), pp. 102-111. doi: 10.23917/ppd.v3i2.2773.

Riduwan and Akdon (2020) Rumus dan Data dalam Analisis Statistika. Bandung: Alfabeta.

Rismawati, E., Widodo, M. and Agustina, E. S. (2015) 'Kelayakan Penyajian Buku Teks Mahir Berbahasa Indonesia Kelas VII SMP/MTS Kurikulum 2013', Jurnal Kata (Bahasa, Sastra, dan Pembelajarannya), 3(5), pp. $1-10$.

Rodiyana, R. (2015) 'Pengaruh Penerapan Strategi Pembelajaran Inkuiri Terhadap Kemampuan Berpikir Kritis Dan Kreatif Siswa SD', Jurnal Cakrawala Pendas, I(1), pp. 34-43.

Safitri, D. and Hartati, T. A. W. (2016) 'Kelayakan Aspek Media, dan Bahasa Dalam Pengembangan Buku Ajar dan Multimedia Interaktif Biologi Sel', Florea, 3(2), pp. 9-14. doi: 10.1093/oseo/instance.00168128.

Samsu, N. et al. (2020) 'Analisis Kelayakan dan Kepraktisan Modul Praktikum Berbasis Literasi Sains untuk Pembelajaran IPA', Jurnal IPA E Pembelajaran IPA, 4(1), pp. 29-40. doi: 10.24815/jipi.v4i1.15546.

Sari, T., Hasnunidah, N. and Marpuang, R. (2018) 'Pengembangan Buku Penuntun Praktikum Energi dalam Sistem Kehidupan dengan Model Argument Driven Inquiry (ADI)', Jurnal Bioterdidik Wahana Ekspresi Ilmiah, 6(1), pp. 1-12. Available at: http://jurnal.fkip.unila.ac.id.

Sugiyono (2018) Metode Penelitian Kuantitatif Kualitatif dan REDD. Bandung: Alfabeta.

Suparman, Badjuri and Anwar, K. (2018) 'Keefektifan Model Pembelajaran PBL Terhadap Peningkatan Prestasi Belajar Dimensi Tiga Pada Siswa Kelas XII IPA', Jurnal Ilmu Sejarah. Sosial, Budaya dan Kependidikan, 5(2), pp. 116-128.

Suryanti, Santoso, H. and Lisminingsih, R. D. (2020) 'Studi Osifikasi dan Morfokinetik Berudu Katak Rana catesbeiana Shaw. dengan Alizarin Red', 5(2), pp. 52-58.

Toyep, M. (2012) 'Pengaruh Pembelajaran Inkuiri Dengan Strategi Problem Posing Pada Materi Fluida Statik Terhadap Kemampuan Metakognitif Siswa', 2(2), pp. 121-126.

Truman, J. W. (2019) 'The Evolution of Insect Metamorphosis', Current Biology, 29(23), pp. R1252-R1268. doi: 10.1016/j.cub.2019.10.009.

Widyaningrum, D. A. and Wijayanti, T. (2019) 'Implementasi buku petunjuk praktikum biokimia berbasis inkuiri terbimbing untuk meningkatkan kemampuan kerja ilmiah', Edubiotik: Jurnal Pendidikan, Biologi dan Terapan, 4(02), pp. 58-67. doi: 10.33503/ebio.v4i02.437. 